\title{
Effects of space and environment on phytoplankton distribution in subtropical reservoirs depend on functional features of the species
}

\author{
Alfonso Pineda ${ }^{1}$ (D) - Jascieli Carla Bortolini ${ }^{2} \cdot$ Luzia Cleide Rodrigues $^{3,4}$
}

Received: 17 September 2020 / Accepted: 12 November 2021 / Published online: 27 November 2021

(c) The Author(s), under exclusive licence to Springer Nature Switzerland AG 2021

\begin{abstract}
Environmental factors and dispersal can influence the structure of biological communities. Their effects can depend on the functional features of the species in the community. Since species belonging to the same trophic level, such as phytoplankton, may show functional differences, we investigated whether the effects of environment and dispersal differ among phytoplankton species from different functional groups. We analyzed data from a rainy and a dry period in 30 reservoirs in a subtropical region. In both periods, the environment as well as high and limited dispersal influenced the metacommunity structure. The functional groups had a low correspondence in their response to both dispersal and environment. Our results showed that the influence of the processes underlying the structure of the metacommunities, such as species sorting (environment influence), mass effect (high dispersal), and neutral dynamics (limited dispersal), depended on the functional characteristics of the organisms and could vary even among species of the same trophic level. These findings suggested that species at the same trophic level could not be considered ecological equivalents. This paper includes a Portuguese and Spanish version of the abstract in the online resources.
\end{abstract}

Keywords Metacommunities $\cdot$ PCNM $\cdot$ Functional diversity $\cdot$ Cyanobacteria $\cdot$ Plankton $\cdot$ Biovolume

\section{Introduction}

The structure of biological communities (e.g., species composition and abundance) varies in time and space, being influenced by environmental factors (environmental conditions and biotic interactions) and dispersal (Heino et al.

Alfonso Pineda, Jascieli Carla Bortolini and Luzia Cleide Rodrigues have contributed substantially to this work.

Alfonso Pineda

amanecce@gmail.com

1 Programa de Pós-Graduação Em Biologia Comparada-PGB, Universidade Estadual de Maringá-UEM, Maringá, PR, Brazil

2 Departamento de Botânica, Instituto de Ciências Biológicas (ICB), Universidade Federal de Goiás-UFG, Goiânia, GO, Brazil

3 Programa de Pós-Graduação em Ecologia de Ambientes Aquáticos Continentais-PEA, Universidade Estadual de Maringá-UEM, Maringá, PR, Brazil

4 Núcleo de Pesquisas em Limnologia e Aquicultura-Nupélia, Universidade Estadual de Maringá-UEM, Maringá, PR, Brazil
2015; Datry et al. 2016). Understanding how those processes act on the communities is crucial to conservation and management of ecosystems (Hubbell 2001; Cassemiro and Padial 2008). For instance, by evaluating the influence of local conditions and dispersal on biodiversity, one could determine if conservation efforts should concentrate on restoring the local conditions (e.g., reducing a certain stressor) or enhancing the connectivity among the communities (to guarantee exchange of species).

The effects of environment and dispersal on communities may vary among trophic levels due to particular features of the organisms (e.g., life history) that cause them to react differently to extrinsic factors (e.g., environmental variation and spatial discontinuity). For instance, the distribution of larger organisms would be limited mainly by dispersal (Padial et al. 2014). In the case of microorganisms such as phytoplankton, it has been proposed that mainly environmental conditions drive their distribution, while dispersal could not be an important process (Cermeño et al. 2010; Astorga et al. 2012; Padial et al. 2014) since microorganisms have high dispersal rates (e.g., Finlay 2002; Cermeño et al. 2010). 
Recent evidence, however, indicates that microorganisms may exhibit spatial patterns that are not associated exclusively with the spatial variation of environmental conditions, but also with dispersal (Van Der Gucht et al. 2007; Declerck et al. 2013). Spatial proxies have been used as signals of dispersal (see Heino et al. 2015), and with this approach, several studies have provided evidence that space (i.e., dispersal) influences the structure of microorganism assemblages (Beisner et al. 2006; Heino et al. 2010; Padial et al. 2014; Bortolini et al. 2019). However, few studies have explored the question of whether a significant effect of space on community structure was related to high or limited dispersal. This accuracy is important to determine strategies for management and conservation of biological systems (Trakhtenbrot et al. 2005). It is necessary, for instance, to understand if, in a particular case, it would be necessary to increase connectivity among sites (to foster the arrival of species) or to decrease it (to prevent influx of unwanted species, such as toxic algae in aquatic systems).

Species belonging to the same trophic level exploit resources similarly, and according to Hubbell (2001), they should react in the same way to environmental variation and show the same dispersal probability. However, these species can react differently to variations in environmental conditions and space, since they may have morphological, metabolic, and functional differences (Salmaso et al. 2015). For instance, in stratified environments, phytoplankton species will vary in their sedimentation rate, since "heavy" algae (e.g., organisms with a silica carapace) could settle faster than those with some mechanism controlling their position in the water column (e.g., flagella and aerotope) (Padisák et al. 2003). In another example, species with protection from desiccation (e.g., mucilaginous matrix in some colonial algae) may tolerate longer travels and reach more-distant sites (traveling in the feathers of birds, for example) than species without some specialized protection. One can expect that species that share morpho-functional features will have a similar response to external stimuli, and species with low similarity will be influenced by different factors.

We aimed to determine the roles of environmental and spatial processes (high and limited dispersal) in the distribution of phytoplankton species with different morphofunctional characteristics. We hypothesized that, although phytoplankton constitutes a single trophic level, the species are not ecological equivalents and the effects of environment and space vary among different morpho-functional groups of phytoplankton species. We expected that species from different groups could show low concordance in their responses to the environment and space. We were also interested in determining the main environmental and spatial drivers of the variation in each morpho-functional group. To test our hypothesis, we used phytoplankton and environmental data from 30 reservoirs located in six basins in a subtropical region, distributed in an area of ca. $200,000 \mathrm{~km}^{2}$, with different environmental conditions and degrees of connectivity.

\section{Materials and methods}

\section{Study area}

The study included 30 reservoirs in an area of ca. 200,000 $\mathrm{km}^{2}$ in a subtropical region in South America (between $22^{\circ}$ and $27^{\circ} \mathrm{S}$ and $49^{\circ}$ and $55^{\circ} \mathrm{W}$ ) (Fig. 1). The reservoirs
Fig. 1 Distribution of the reservoirs. Table 1 shows details for sites

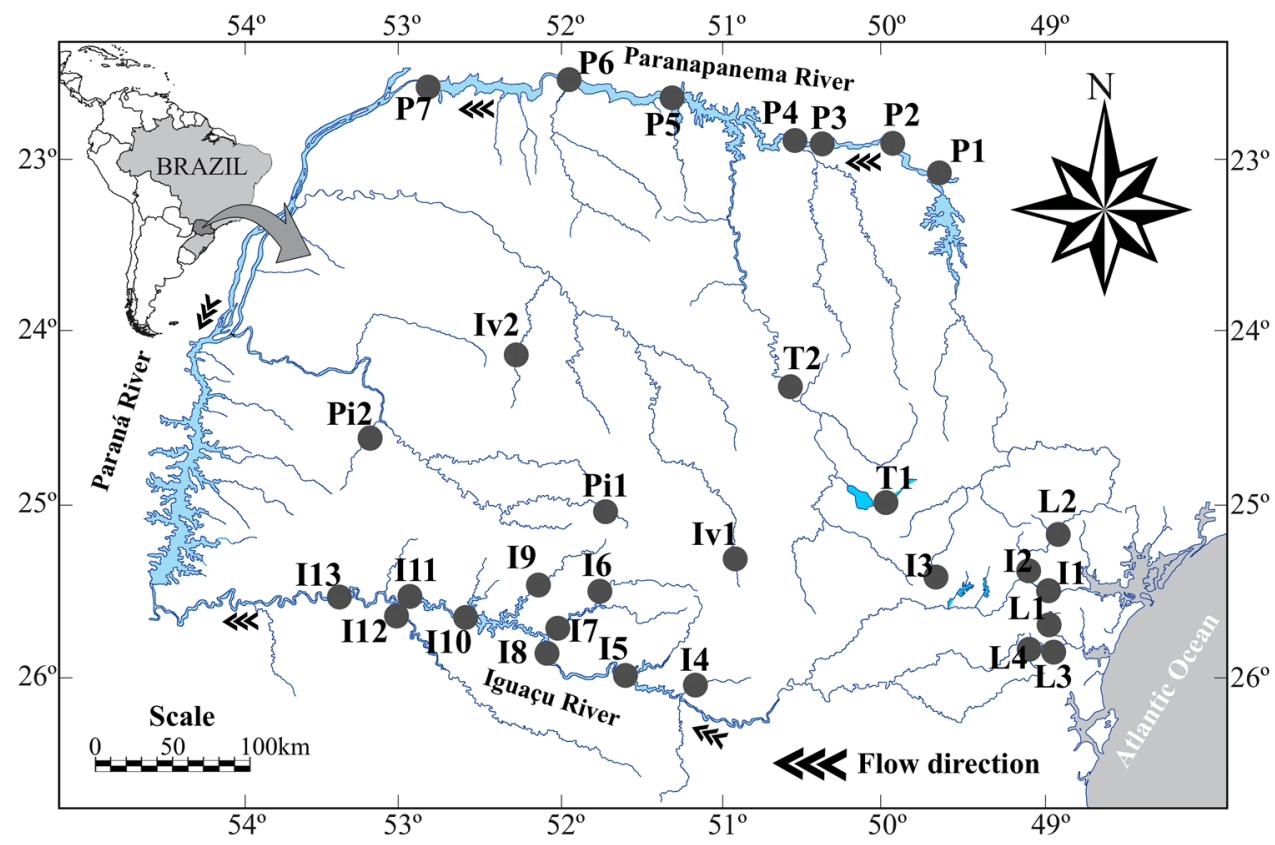


belong to the Paraná basin, specifically to the sub-basins of the rivers Tibagi, Iguaçú, Paranapanema, Piquirí, Ivaí, and the Litorânea basin. The reservoirs were constructed between 1909 and 2001 and have different degrees of connectivity. While some of them are arranged in cascades (e.g., reservoirs along the Paranapanema and Iguaçú Rivers), others do not show connectivity, either directly or indirectly. The area of the lacustrine zone ranges from 0.1 to $419 \mathrm{~km}^{2}$, while the water retention time ranges from $<10$ to $>300$ days (Table 1). Most of the reservoirs are used for electricity production and some of them for recreation, drinking-water supply, and irrigation.

\section{Phytoplankton sampling and analysis}

The samples were collected directly with bottles at the subsurface in the pelagic zone of the lacustrine area of the reservoirs. We fixed them with $1 \%$ acetic Lugol's solution. We conducted sampling twice in 2001, covering the dry (July) and rainy (December) periods. The counts of individuals (cells, filaments, and colonies) followed Utermöhl (1958) and Lund et al. (1958). Biovolume $\left(\mathrm{mm}^{3} \mathrm{~L}^{-1}\right)$ was used as a biomass estimate and calculated as the product of the volume of each taxon and its density (individuals $\mathrm{mL}^{-1}$ ). The volume of each taxon was calculated by approximating its shape to geometric forms (e.g., cylinders and cones) (Sun and Liu 2003).

We categorized the phytoplankton taxa into morphologybased functional groups (MBFG, Kruk et al. 2010). We based the grouping on the shared morpho-functional traits of the species. MBFG includes seven groups of species that differ in size, form, and presence of specialized features (Fig. 2). We chose the MBFG approach since it has shown a better response to environmental variation at broad scales

Table 1 General information about the reservoirs. RT, water residence time (days)

\begin{tabular}{|c|c|c|c|c|c|c|c|c|}
\hline Basin & Reservoir & Code1 & Code & $\begin{array}{l}\text { Altitude } \\
\text { (m) }\end{array}$ & RT (days) & Area $\left(\mathrm{km}^{2}\right)$ & Perimeter $(\mathrm{km})$ & Start of operation \\
\hline Iguaçú & Piraquara & I1 & $\mathrm{Pi}$ & 742 & 438 & 3.3 & 4 & 1979 \\
\hline Iguaçú & Iraí & $\mathrm{I} 2$ & I & 918 & 240 & 15 & 20.1 & 2000 \\
\hline Iguaçú & Passaúna & $\mathrm{I} 3$ & $\mathrm{P}$ & 921 & 420 & 14 & 35.3 & 1991 \\
\hline Iguaçú & Salto do Vau & I4 & SV & 832 & 1 & 2 & 4 & 1959 \\
\hline Iguaçú & Foz do Areia & I5 & FA & 785 & 150 & 139 & 288 & 1980 \\
\hline Iguaçú & Salto Curucaca & I6 & $\mathrm{Cu}$ & 904 & 1 & 2 & 3.7 & Unknown \\
\hline Iguaçú & Jordão & I7 & $\mathrm{J}$ & 619 & 183 & 3.4 & 21.7 & 1996 \\
\hline Iguaçú & Segredo & I8 & $\mathrm{Se}$ & 643 & 47 & 80.4 & 175 & 1992 \\
\hline Iguaçú & Cavernoso & I9 & $\mathrm{Cv}$ & 868 & 0.5 & 2.9 & 3.7 & 1950 \\
\hline Iguaçú & Salto Santiago & $\mathrm{I} 10$ & SS & 636 & 110 & 208 & 377 & 1979 \\
\hline Iguaçú & Salto Osório & I11 & $\mathrm{SO}$ & 398 & 16 & 51 & 180 & 1975 \\
\hline Iguaçú & Foz do Chopim & $\mathrm{I} 12$ & $\mathrm{FC}$ & 373 & 0.5 & 2.9 & 5.3 & 2001 \\
\hline Iguaçú & Salto Caxias & $\mathrm{I} 13$ & $\mathrm{SC}$ & 347 & 33 & 124 & 267 & 1998 \\
\hline Ivai & Rio dos Patos & Iv1 & $\mathrm{Pa}$ & 697 & 0.2 & 13 & 32 & 1917 \\
\hline Ivai & Mourão & Iv2 & Mo & 598 & 70 & 11.3 & 60 & 1964 \\
\hline Litorânea & Guaricana & L1 & G & 780 & 13 & 7 & 7.2 & 1957 \\
\hline Litorânea & Capivari & L2 & $\mathrm{Ca}$ & 816 & 48 & 12 & 123.5 & 1970 \\
\hline Litorânea & Salto do Meio & L3 & Sme & 850 & 0.5 & 0.1 & 3.9 & 1949 \\
\hline Litorânea & Vossoroca & L4 & V & 921 & 110 & 5.1 & 18.5 & 1949 \\
\hline Paranapanema & Chavantes & $\mathrm{P} 1$ & $X$ & 491 & 353 & 400 & 402 & 1970 \\
\hline Paranapanema & Salto Grande & $\mathrm{P} 2$ & SG & 407 & 1.4 & 12 & 25 & 1958 \\
\hline Paranapanema & Canoas II & P3 & CII & 410 & 4.4 & 22.5 & 66 & 1992 \\
\hline Paranapanema & Canoas I & P4 & $\mathrm{CI}$ & 384 & 6 & 30.8 & 74 & 1999 \\
\hline Paranapanema & Capivara & P5 & $\mathrm{C}$ & 360 & 127 & 419.3 & 738 & 1975 \\
\hline Paranapanema & Taquaruçu & P6 & $\mathrm{T}$ & 313 & 7.9 & 80.1 & 156 & 1989 \\
\hline Paranapanema & Rosana & $\mathrm{P} 7$ & $\mathrm{R}$ & 293 & 19 & 220 & 230 & 1986 \\
\hline Piquiri & Santa María & Pi1 & SM & 904 & 2 & 0.1 & 2 & Unknown \\
\hline Piquiri & Melissa & Pi2 & M & 339 & 0.5 & 2.9 & 3.5 & 1962 \\
\hline Tibagi & Alagados & $\mathrm{T} 1$ & A & 944 & 46 & 7.2 & 47 & 1909 \\
\hline Tibagi & Harmonia & $\mathrm{T} 2$ & $\mathrm{H}$ & 720 & 13 & 3 & 7.5 & 1953 \\
\hline
\end{tabular}




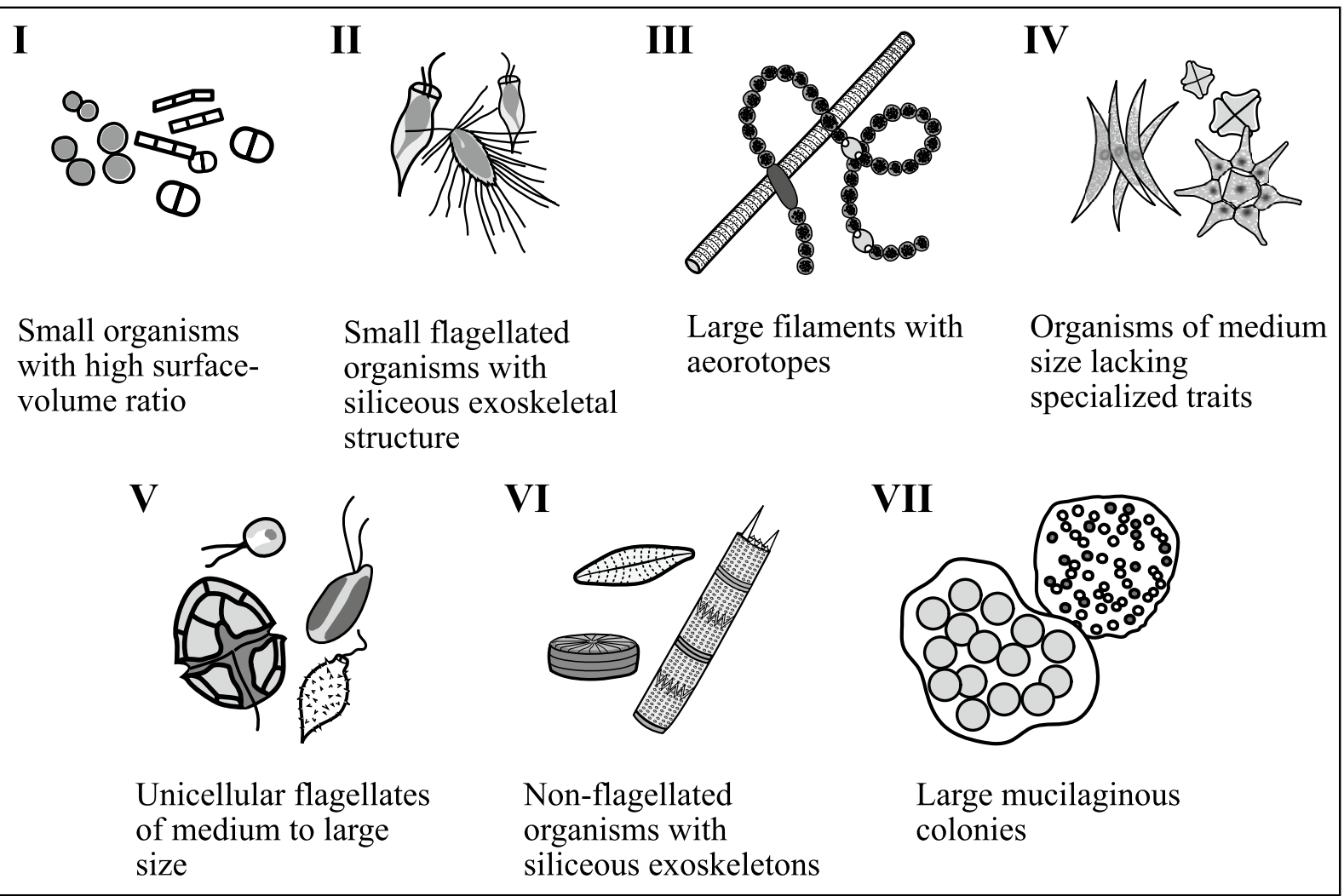

Fig. 2 Seven morphology-based functional groups (Kruk et al. 2010). Algae sizes in the figure do not represent true size-scale relationships among groups

than groups based on other classification methods (Kruk et al. 2011).

The functional-groups approach assumes that species in a specific group react in the same way to external stimuli and that the differences among groups are greater than the differences among species within a group. This approach has allowed identification of the key temporal and spatial processes underlying the community assemblage (e.g., Rodrigues et al. 2018; Pineda et al. 2020), due to the deterministic relationship that can be established between ecological processes and functional traits. For instance, the body size allows identification of the effect of grazing, since smaller phytoplankters (e.g., MBFG I) are more palatable than larger ones (e.g., MBFG VII) (Lehman 1991). In another example, for stagnant water habitats, while silica-shelled organisms (MBFG VI) sink rapidly due to their high weight, organisms with aerotopes (MBFG III) sink slowly due to their buoyancy (Kruk et al. 2010).

\section{Environmental and biotic explanatory variables}

Simultaneously with the phytoplankton, we collected samples of zooplankton and environmental variables. We expressed zooplankton density as ind. $\mathrm{m}^{-3}$ and separated the zooplankton into nine categories: testate amoebae, rotifers, cladocerans, calanoid nauplii, calanoid copepodites, calanoid adults, cyclopoid nauplii, cyclopoid copepodites, cyclopoid adults, and heterotrophic flagellates. We used different zooplankton groups because each one can graze on different phytoplankton species, based on their size and shape.

We also measured the variables $\mathrm{pH}$, water temperature $\left({ }^{\circ} \mathrm{C}\right)$, conductivity $\left(\mu \mathrm{S} \mathrm{cm}^{-1}\right)$, turbidity (NTU), depth $\left(Z_{\max }\right.$ in $\mathrm{m})$, wind $\left(\mathrm{m} \mathrm{s}^{-1}\right), \mathrm{P}_{-} \mathrm{PO}_{4}\left(\mathrm{mg} \mathrm{L}^{-1}\right), \mathrm{N}-\mathrm{NO}_{3}{ }^{-}\left(\mathrm{mg} \mathrm{L}^{-1}\right)$, and $\mathrm{N}-\mathrm{NH}_{4}{ }^{+}\left(\mathrm{mg} \mathrm{L}^{-1}\right)$. We estimated the euphotic zone $\left(Z_{\text {eu }}\right.$ in $\mathrm{m}$ ) as 2.7 times the Secchi disk depth (Cole 1994), and we calculated the mixing zone $\left(Z_{\text {mix }}\right.$ in $\mathrm{m}$ ) from temperature profiles. We used the $Z_{\text {mix }}: Z_{\text {max }}$ ratio as a measure of the water column stability, with values close to one considered as more unstable. We used the $Z_{\text {eu }}: Z_{\text {mix }}$ ratio as a measure of light availability in the mixing zone (Jensen et al. 1994). We also recorded the altitude $(\mathrm{m})$, area $\left(\mathrm{km}^{2}\right)$, perimeter $(\mathrm{km})$, and water retention time (days) of the reservoirs (provided by the management company of each reservoir). Details about the measured environmental factors and zooplankton sampling can be found in Simões et al. (2015). We classified the environmental factors according to the processes they represented, as chemical (factors affecting metabolism, 
including light availability) or physical (related to factors with no direct effect on metabolism) (Table 2).

\section{Spatial factors}

We used spatial factors as a proxy of the effect of dispersal on the community structure. The spatial variables (eigenvectors) were generated using the analysis of principal coordinates neighbor matrices (PCNM; Borcard and Legendre 2002), which consists of a principal components analysis based on a matrix of geographic distances. The PCNMs obtained for this analysis model different spatial structures (Borcard and Legendre 2002) and can be used together with environmental variables in variation-partitioning analysis (Anderson and Cribble 1998) as a way to understand the processes underlying a community assemblage (Borcard and Legendre 2002).
We obtained 17 PCNMs with positive eigenvalues that were categorized as representing fine or broad spatial scales. PCNMs with smaller eigenvalues (in this study, PCNM 5 to PCNM 17) represented the fine scale (DinizFilho and Bini 2005; Griffith and Peres-Neto 2006) and were interpreted as a signal of high dispersal, which indicates the influence of a mass-effect dynamic (Heino et al. 2015). PCNMs with higher eigenvalues (in this study, PCNM 1 to PCNM 4) represented the broad scale (DinizFilho and Bini 2005; Griffith and Peres-Neto 2006) and were related to dispersal limitation, which indicates the influence of a neutral dynamic (Heino et al. 2015). To split the PCNMs into these scales, we drew maps with the PCNMs (Online resource 2, S3) and grouped them according to the spatial pattern they represented, as suggested by Borcard et al. (2011).
Table 2 Mean values, standard deviation (SD), and variation coefficient (VC-\%) of chemical, physical, and biotic factors measured in the rainy and dry periods for the 30 reservoirs

\begin{tabular}{|c|c|c|c|c|c|c|}
\hline & \multicolumn{3}{|l|}{ Rainy } & \multicolumn{3}{|l|}{ Dry } \\
\hline & Mean & SD & $\mathrm{VC}$ & Mean & SD & VC \\
\hline \multicolumn{7}{|l|}{ Chemical } \\
\hline $\mathrm{pH}$ & 7.5 & 0.6 & 8 & 6.2 & 1.4 & 23 \\
\hline $\mathrm{N}-\mathrm{NO}_{3}^{-}\left(\mathrm{mg} \mathrm{L}^{-1}\right)$ & 251.5 & 204 & 81 & 331.5 & 183.6 & 55 \\
\hline $\mathrm{N}-\mathrm{NH}_{4}^{+}\left(\mathrm{mg} \mathrm{L}^{-1}\right)$ & 14.5 & 10.9 & 75 & 29.4 & 36.2 & 123 \\
\hline$Z_{\text {eu }}(\mathrm{m})$ & 4.3 & 2.4 & 56 & 4.9 & 2.5 & 51 \\
\hline$Z_{\mathrm{eu}}: Z_{\mathrm{mix}}$ & 0.9 & 0.8 & 89 & 0.6 & 1.2 & 200 \\
\hline Turbidity (NTU) & 13.2 & 25.9 & 196 & 9.2 & 10.8 & 117 \\
\hline Conductivity $\left(\mu \mathrm{S} \mathrm{cm}^{-1}\right)$ & 44.8 & 20.1 & 45 & 38.2 & 15.2 & 40 \\
\hline$T\left({ }^{\circ} \mathrm{C}\right)$ & 23.8 & 2.9 & 12 & 18 & 4.8 & 27 \\
\hline $\mathrm{P}-\mathrm{PO}_{4}\left(\mathrm{mg} \mathrm{L}^{-1}\right)$ & 4.1 & 5.3 & 129 & 2.9 & 2.1 & 72 \\
\hline \multicolumn{7}{|l|}{ Physical } \\
\hline Wind $\left(\mathrm{m} \mathrm{s}^{-1}\right)$ & 2.9 & 2.1 & 72 & 3.5 & 3 & 86 \\
\hline Altitude (m) & 640.4 & 227.5 & 36 & 640.4 & 227.5 & 36 \\
\hline$Z_{\max }(\mathrm{m})$ & 29.4 & 32.6 & 111 & 30.4 & 32.8 & 108 \\
\hline$Z_{\text {mix }}: Z_{\max }$ & 0.5 & 0.3 & 60 & 0.7 & 0.3 & 43 \\
\hline Area $\left(\mathrm{km}^{2}\right)$ & 63.1 & 111.5 & 177 & 63.1 & 111.5 & 177 \\
\hline Perimeter $(\mathrm{km})$ & 106.9 & 166.9 & 156 & 106.9 & 166.9 & 156 \\
\hline Residence time (days) & 82 & 125.7 & 153 & 82 & 125.7 & 153 \\
\hline \multicolumn{7}{|l|}{ Biotic (ind $\mathrm{m}^{-3}$ ) } \\
\hline Testate amoebae & 3885 & 20,904 & 538 & 226 & 482 & 213 \\
\hline Rotifera & 28,424 & 42,404 & 149 & 22,055 & 51,429 & 233 \\
\hline Cladocera & 35,479 & 130,949 & 369 & 26,477 & 101,646 & 384 \\
\hline Calanoid nauplii & 8053 & 17,561 & 218 & 1066 & 2421 & 227 \\
\hline Calanoid copepodites & 6818 & 12,387 & 182 & 2472 & 8605 & 348 \\
\hline Calanoid adults & 1056 & 1908 & 181 & 132 & 256 & 194 \\
\hline Cyclopoid nauplii & 10,714 & 22,276 & 208 & 12,465 & 32,025 & 257 \\
\hline Cyclopoid copepodites & 5507 & 15,069 & 274 & 4371 & 13,423 & 307 \\
\hline Cyclopoid adults & 351 & 862 & 245 & 999 & 4444 & 445 \\
\hline Heterotrophic flagellates & 3185 & 3734 & 117 & 1832 & 2098 & 115 \\
\hline
\end{tabular}

$Z_{\text {max }}$ depth max, $Z_{e u}$ euphotic zone, $Z_{\text {mix }}$ mixing zone, $T$ water temperature 


\section{Data analysis}

To characterize the temporal variation in environmental conditions and to test for environmental differences between the rainy and dry periods, we used a constrained analysis of principal coordinates (CAP; Anderson and Willis 2003) on the Euclidean distance for scaled variables.

To assess the effects of environmental and spatial factors on the variation of the biomass phytoplankton, we used a partial redundancy analysis (pRDA; Borcard et al. 1992). As response, we used nine matrices of biovolume values: one including all the species, one with all the MBFGs, and one for the species in each MBFG (seven matrices). As explanatory, we used two explanatory matrices: one with environmental factors and one with the PCNMs.

We also used pRDA to evaluate the importance of each kind of environmental factor. For this, we split the environmental factors into three explanatory matrices according to the processes to which they were most related: physical, chemical, and biotic (Table 2). For these pRDAs, we also included as explanatory one matrix with the 17 PCNMs to remove the effect of space from the environment-species (or groups) relationship. Then, we evaluated the effect of the broad and fine spatial scales, again with pRDA, by separating the PCNMs into two explanatory matrices according to the spatial scale they represented. For these pRDAs, we also included one matrix with the total of the environmental factors, since we were interested in determining the pure influence of space on the species (or groups), excluding any interaction of space with environmental factors. For all pRDAs, we used Monte Carlo permutation tests (9999 permutations) to assess the significance of the fractions (Borcard et al. 1992). As a measure of the explained variation of the explanatory matrices, we considered only the pure fractions, as well as the adjusted $R^{2}$ values, since this corrects for the effect of differences in the number of independent variables in the explanatory matrices and allows comparison of results (Peres-Neto et al. 2006).

To evaluate the level of concordance of the responses of species in different functional groups to the total of explanatory factors (environmental and spatial factors in a single matrix) in each period, we ran a Procrustean Randomization Test (ProTest; Jackson 1995) on the ordination (sites) generated by the redundancy analysis (RDA), performed separately for each MBFG (seven response matrices). We also tested concordance for the same group between periods. In all cases, we evaluated (9999 permutations) the level of agreement between ordinations as the sum of squares of the residuals, $\mathrm{m}^{2}$ (Jackson 1995). Lower values of the $\mathrm{m}^{2}$ statistic indicate a high association between the responses of functional groups, and higher values indicate a low association. For our main objective of understanding whether species react in the same way to the environment and space, the Procrustes analysis complemented the pRDAs, since environment and space can influence two MBFGs with the same force ( $R^{2}$ adjusted in the pRDA), but how each MBFG relates to those explanatory factors may be different (i.e., differences in the significant explanatory factors and ordination, or RDA).

As a previous step to the pRDA and RDA, we performed a variable selection using a forward procedure $(p<0.05,999$ permutations) for each explanatory matrix. The response matrix was Hellinger-transformed and the environmental factors were log-transformed (except the $\mathrm{pH}$ and ratios). The Hellinger transformation is a recommended way of handling community data sets with many zeros (as in our case) without overweighting the rare species (Legendre and Gallagher 2001). We investigated the collinearity with the variation inflation factor (VIF). We removed from the analyses all variables with a VIF higher than 10 (Legendre and Legendre 1998). We ran the analyses and plots in the R software ( $R$ Development Core Team 2021), using the vegan (Oksanen et al. 2007), ggplot2 (Wickham 2016), and adespatial (Dray et al. 2018) packages.

\section{Results}

\section{Environmental variability in reservoirs}

In both the rainy and dry periods, environmental conditions showed high spatial variation (Table 2), especially related to light availability (in the dry period, variation coefficientVC $>100 \%$ for turbidity and $Z_{\mathrm{eu}}: Z_{\max }$ ), nutrient concentrations ( $\mathrm{VC}>70 \%$ for $\mathrm{P}-\mathrm{PO}_{4}$ and $\mathrm{N}-\mathrm{NH}_{4}{ }^{+}$), and zooplankton abundance ( $\mathrm{VC}>110 \%$ in all cases). CAP showed environmental differences between periods $(F=5.97, p=0.001)$. The sites in the rainy period were related mainly to higher temperature, $\mathrm{pH}$, and light availability $\left(Z_{\mathrm{eu}}: Z_{\max }\right.$ ratio), while in the dry period, the sites were mainly associated with high nitrate and ammonium concentrations and high water-column mixing ( $Z_{\text {mix }}: Z_{\max }$ ratio) (Fig. 3).

\section{Phytoplankton and MBFG}

In total, 140 phytoplankton taxa were recorded, 106 in the rainy and 101 in the dry period (Online resource 1). MBFG IV showed the highest number of taxa (51) and MBFG I the lowest (3). We recorded all the groups in both the rainy and dry periods, although they were not present in all reservoirs (Fig. 4). The biovolume values of all MBFGs showed a high spatial variation (Fig. 4). Filamentous algae (MBFG III, mean values dry $=4.42 \mathrm{~mm}^{3} \mathrm{~L}^{-1}$, rainy $=0.82 \mathrm{~mm}^{3} \mathrm{~L}^{-1}$ ), flagellates (MBFG V, mean values dry $=0.35 \mathrm{~mm}^{3} \mathrm{~L}^{-1}$, rainy $=0.68 \mathrm{~mm}^{3} \mathrm{~L}^{-1}$ ), and diatoms (MBFG VI, mean values dry $=0.20 \mathrm{~mm}^{3} \mathrm{~L}^{-1}$, rainy $=0.40 \mathrm{~mm}^{3} \mathrm{~L}^{-1}$ ) showed the 


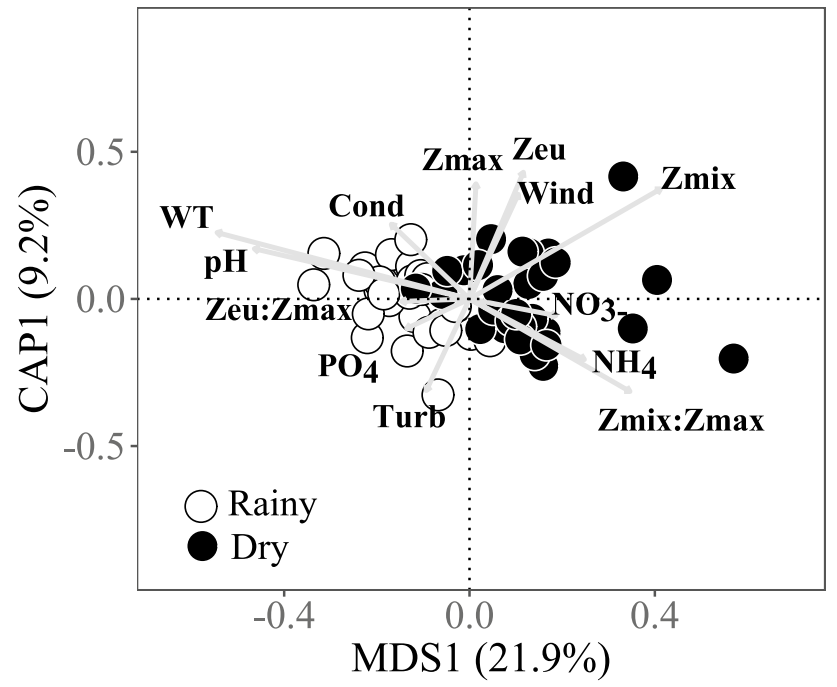

Fig. 3 Environmental temporal variation of the 30 reservoirs represented on the first two axes of a constrained principal coordinates analysis

highest biovolume values (more details in Online resource 1) and dominated in most of the reservoirs (Fig. 4).

\section{Environmental and spatial drivers of the MBFGs}

Both environmental and spatial factors were selected as explanatory factors of the phytoplankton community, except for the total MBFG in both the rainy (no spatial factors selected) and dry (none selected) periods and for the species belonging to MBFG I in the rainy period (no spatial factors selected). The selected factors varied among the MBFGs and changed over time (Table 3 ).

Regarding the total of species, the pRDA showed that the environment was more important for the biovolume variation than space (Table 4). However, the importance of the environment (physical, chemical, and biotic factors) and space (fine-scale-high dispersal and broad-scale-limited dispersal) varied between periods and among MBFGs (Table 4). No relationship between the phytoplankton community and the environment emerged when analyzing the MBFG level in the dry period and MBFG I in the rainy period.

Although initially the effect of the total environment and total space could be significant, the explanation of their split fractions decreased (even turning null) due to the high values of the shared fractions (not shown) that indicate the interaction among factors. In general, ProTest Analysis showed low concordance among the MBFGs (Table 5), and even significant results showed low concordance $\left(\mathrm{m}^{2}\right.$ values higher than 73), indicating that species in each MBFG responded in different ways to environmental variation. The MBFGs also showed lower concordance between periods.

\section{Discussion}

Are the species from the same trophic level ecological equivalents? By analyzing a polyphyletic community of species that are strongly dependent on light and nutrient availability, such as phytoplankton (including cyanobacteria), and its relationship with environmental and dispersal processes, we found that the answer is no. The influence of the ecological processes, as well as both high and limited dispersal, depended on the features of the phytoplankton species and the period of the year. Our findings contrast with the idea that species at the same trophic level are ecological equivalents and that their distribution would be related exclusively to dispersal and ecological drift, with no relationship to environmental variation (Hubbell 2006).

\section{Effect of environment on phytoplankton variation}

One could expect a stronger relationship between the community and the environment at the functional level (e.g., MBFG) than at the species level (Mutshinda et al. 2016), since environmental filtering and biotic interactions shape communities through selection of the functional traits of species (e.g., Noble and Slatyer 1980). In our case, however, this was true only in the rainy period. In the dry period, the environment did not explain the variation of the whole community when the MBFG was analyzed (no factor was selected). Although MBFGs are based on morphological features that reflect some physiological traits of the species (e.g., smaller size is related to higher nutrient uptake) (Kruk et al. 2010), in our case, it appeared that MBFGs did not reflect the species traits that were influenced by the environment. For instance, the selection of environmental factors in the dry period showed that $\mathrm{pH}$ and calanoid copepodites were important drivers for the species variation, but the MBFGs were not. Thus, although grouping species based on their morphology can help to understand the processes that shape the communities (such as in the rainy period); in some cases, the species morphological characteristics considered by the MBFG could not allow us to identify the response of some physiological traits (e.g., tolerance to water acidity) to environmental variations (e.g., change in $\mathrm{pH}$ ) or the influence of significant interspecific dynamics (e.g., grazing). Therefore, identifying the main drivers of the community based on functional groups could be difficult in some cases.

When analyzing the whole community at the species level, we found that mainly environmental factors drove the phytoplankton variation, as found in other studies (Beisner et al. 2006; De Bie et al. 2012; Padial et al. 2014; Huszar et al. 2015; Machado et al. 2016; Santos 
Fig. 4 Spatial variation of the biovolume $\left(\mathrm{mm}^{3} \mathrm{~L}^{-1}\right)$ total and relative contributions of the morphology-based functional groups (MBFG) in the rainy and dry periods. See code names in Table 1
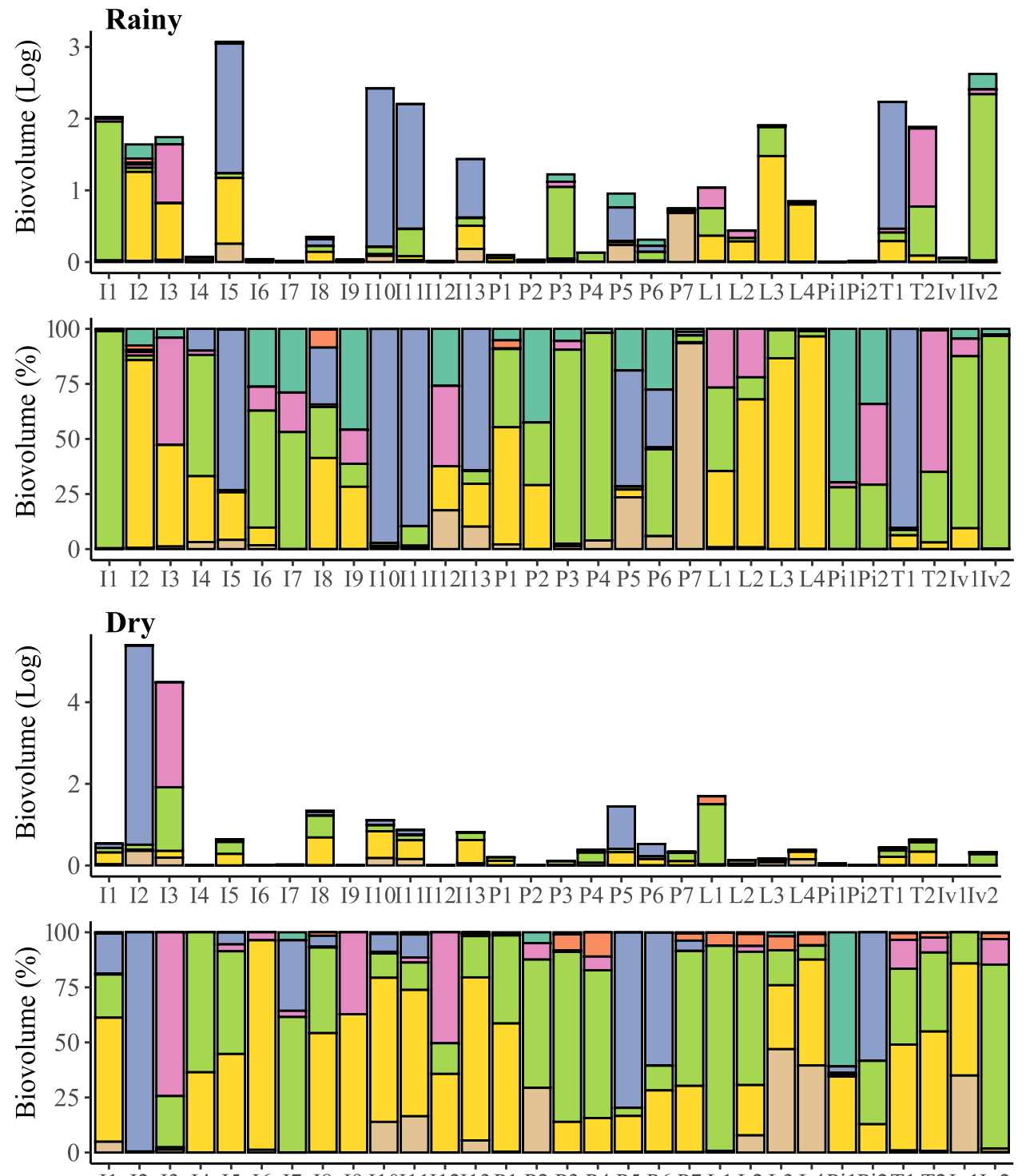

I1 I2 I3 I4 I5 I6 I7 I8 I9 I10I11I12I13P1 P2 P3 P4 P5 P6 P7 L1 L2 L3 L4Pi1Pi2T1 T2Iv1Iv2

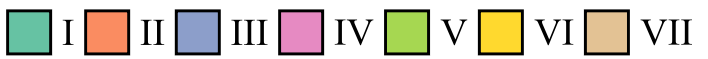

et al. 2016; Wojciechowski et al. 2017; Santana et al. 2018; Bortolini et al. 2020). However, we also found that the influence of the environment (and space, as we will discuss below) depended on the functional features of the phytoplankton. Moreover, each kind of environmental factor (physical, chemical, and biotic) had a different effect on each MBFG. In fact, in most cases, the species of the different MBFGs did not show concordance in their response to the environment (and space). In other words, phytoplankton species belonging to different MBGFs cannot be considered ecological equivalents. Although all the phytoplankters belong to the same trophic level and exploit the same resources, they show different functional traits (e.g., size, shape, presence of mucilage, flagella, and siliceous exoskeleton) influencing the way that they react to the abiotic and biotic characteristics of the reservoirs. For instance, while filamentous species (MBFG III) seemed to be sensitive to the area of the reservoirs, colonial algae (MBFG VII) showed sensitivity to changes in the abundance of zooplankton and the mixing of the water column.

\section{Effect of space on phytoplankton variation}

We showed that other factors aside from the environmental ones influenced the distribution of species. For instance, we observed high residual values in the pRDAs and we found that spatial factors related to broad (dispersal limitation) and fine (high dispersal) scales were important for the distribution of some phytoplankton species. 
Table 3 Selected environmental and spatial factors selected by the forward method in the rainy and dry periods

\begin{tabular}{|c|c|c|c|c|c|}
\hline & \multicolumn{3}{|l|}{ Environmental } & \multicolumn{2}{|l|}{ Spatial } \\
\hline & Physical & Chemical & Biotic & Broad & Fine \\
\hline \multicolumn{6}{|l|}{ Rainy } \\
\hline All species & $Z_{\mathrm{Mix}}: Z_{\mathrm{Max}}$, area & Turbidity & Rotifer & PCNM1 & PCNM9 \\
\hline MBFG I & - & - & - & - & - \\
\hline MBFG II & $Z_{\max }$ & - & Cladocera, HF & PCNM1 & PCNM9 \\
\hline MBFG III & Area & $\mathrm{P}-\mathrm{PO}_{4}$ & Coptocal & PCNM4 & PCNM9 \\
\hline MBFG IV & $Z_{\mathrm{Max}}$, area, $Z_{\mathrm{Mix}}: Z_{\mathrm{Max}}$ & - & Coptocal & PCNM1, PCNM2, PCNM4 & PCNM9 \\
\hline MBFG V & - & - & Rotifers, naupcal, HF & PCNM1 & - \\
\hline MBFG VI & $Z_{\text {Mix }}: Z_{\text {Max }}$ & Turbidity & Adultcycl, adultcal, naupcal & PCNM1 & - \\
\hline MBFG VII & Area & - & Coptocal, HF, cladocera & PCNM1 & PCNM13 \\
\hline All MBFGs & Altitude, area & - & Cladocera, coptocal & - & - \\
\hline \multicolumn{6}{|l|}{ Dry } \\
\hline All species & Area & $\begin{array}{l}\mathrm{pH}, \text { turbidity, } \\
\mathrm{NH}_{4}^{+}, Z_{\mathrm{eu}}: Z_{\mathrm{Mix}}\end{array}$ & Coptocal, HF & PCNM2, PCNM1 & PCNM5, PCNM9 \\
\hline MBFG I & Perimeter & Turbidity, cond & Cladocera & PCNM1, PCNM2 & PCNM9 \\
\hline MBFG II & - & - & Adultcycl, cladocera & PCNM1 & PCNM9, PCNM15 \\
\hline MBFG III & Area & - & Adultcal & PCNM4, PCNM1 & PCNM9, \\
\hline MBFG IV & - & $Z_{\mathrm{eu}}: Z_{\mathrm{Mix}}$ & - & - & $\begin{array}{l}\text { PCNM8, PCNM5, } \\
\text { PCNM9, }\end{array}$ \\
\hline MBFG V & Perimeter & - & HF, coptocycl & - & PCNM5, PCNM9 \\
\hline MBFG VI & $\begin{array}{l}\text { Area, residence time, } \\
Z_{\mathrm{Mix}}: Z_{\mathrm{Max}}\end{array}$ & $Z_{\mathrm{eu}}: Z_{\mathrm{Mix}}, Z_{\mathrm{EU}}$ & Coptocycl, HF & PCNM1, PCNM2 & PCNM9, \\
\hline MBFG VII & - & $\mathrm{N}-\mathrm{NH}_{4}^{+}$ & Coptocycl & PCNM3 & PCNM7 \\
\hline All MBFGs & - & - & - & - & - \\
\hline
\end{tabular}

As spatial factors, 10 PCNMs were selected from the original 17 PCNMs

"_" indicates cases in which no factors were selected

$H F$ heterotrophic flagellates, Coptocal calanoid copepodites, Adultcycl adult cyclopoids, Adultcal adult calanoids, Naupcal calanoid nauplii, Coptocycl cyclopoid copepodites

The significant effect of dispersal limitation suggests that some species could not reach all the sites that possess the appropriate environmental conditions for their establishment. The influence of dispersal limitation was higher for filamentous (MBFG III), flagellates (MBFG V), and colonial (MBFG VII) phytoplankters. These groups include bloomforming and toxigenic cyanobacteria (Kruk et al. 2010; Kruk and Segura 2012), such as Dolichospermum and Raphidiopsis from MBFG III, and Aphanocapsa and Microcystis aeruginosa (Kützing) Kützing from MBFG VII. In the case of representatives from MBFG VII, they can be efficiently dispersed overland (i.e., with viable inocula) by vectors (e.g., Aphanocapsa; Schlichting 1960) and through the air (e.g., Microcystis; Chrisostomou et al. 2009). However, the success of this overland dispersal is limited to a few travel hours and short distances (Schlichting 1960; Chrisostomou et al. 2009). On the other hand, Raphidiopsis raciborskii (Woloszynska) Aguilera, Berrendero Gómez, Kastovsky, Echenique \& Salerno (formerly Cylindrospermopsis raciborskii) (MBFG III) disperses successfully due to its ability to tolerate traveling along river courses (Padisák 1997) and it seems that viable inocula can reach sites as much as $400 \mathrm{~km}$ distant from the source (Hamar 1977). Although our study area includes several reservoirs with high connectivity (such as those in cascades), in other cases, the reservoirs have no direct connection and are very distant for viable inocula to reach. In general, the effect of dispersal limitation on the distribution of MBFG III suggests that, although some reservoirs have the potential to develop representative populations of toxic filamentous algae (e.g., high phosphorus concentration in Iv2), the increase in biomass did not occur, at least in part because of low levels of incoming inocula.

In other cases, high dispersal among sites influenced the spatial variation of phytoplankton biomass. Since some reservoirs possess characteristics favoring phytoplankter development (Reynolds 1999; Borges et al. 2008), such as high water residence time (Souza et al. 2016), they can develop a high biomass which can be exported through both the air and watercourses. In this study, we found high biomasses in several reservoirs (e.g., Irai with $130.54 \mathrm{~mm}^{3} \mathrm{~L}^{-1}$ in the dry 
Table 4 Variation partitioning results, showing the relative contributions (\%) of the environmental and spatial factors to the variation of the biovolume of the phytoplankton species and MBFGs in the rainy and dry periods

\begin{tabular}{|c|c|c|c|c|c|c|c|c|c|}
\hline & Total env & Physical & Chemical & Biotic & Total spatial & Fine & Broad & Env and spatial & Residual \\
\hline \multicolumn{10}{|l|}{ Rainy } \\
\hline All species & $9 *$ & $5^{*}$ & 0 & $3^{*}$ & 3 & 0 & 3 & $17 *$ & 83 \\
\hline MBFG I & - & - & - & - & - & - & - & - & 100 \\
\hline MBFG II & $17 *$ & 2 & - & 11 & 9* & 3 & $6^{*}$ & $30 *$ & 70 \\
\hline MBFG III & $14^{*}$ & $6^{*}$ & 3 & 0 & $17 *$ & 3 & $13 *$ & $38 *$ & 62 \\
\hline MBFG IV & $4 *$ & $4 *$ & - & 1 & $6^{*}$ & 0 & $6^{*}$ & $13 *$ & 87 \\
\hline MBFG V & $19 *$ & - & - & $19 *$ & $10 *$ & - & $10 *$ & $27 *$ & 73 \\
\hline MBFG VI & $15^{*}$ & 2 & 2 & $9 *$ & $3 *$ & - & $3^{*}$ & $19 *$ & 81 \\
\hline MBFG VII & $13^{*}$ & $3 *$ & - & $11^{*}$ & $5^{*}$ & $3 *$ & 1 & $19 *$ & 81 \\
\hline All MBFGs & $21 *$ & $7 *$ & - & 1 & - & - & - & $21 *$ & 79 \\
\hline \multicolumn{10}{|l|}{ Dry } \\
\hline All species & $13 *$ & $3 *$ & 3 & 3 & 4 & 0 & 0 & $23 *$ & 77 \\
\hline MBFG I & $34 *$ & 0 & $15^{*}$ & 0 & 0 & 0 & 0 & $50 *$ & 50 \\
\hline MBFG II & $12 *$ & - & - & $12 *$ & 25 & $18 *$ & 5 & $53 *$ & 47 \\
\hline MBFG III & $14 *$ & $6^{*}$ & - & 0 & $10 *$ & 1 & $10 *$ & $35^{*}$ & 65 \\
\hline MBFG IV & 3 & - & 3 & - & $15^{*}$ & $15^{*}$ & - & $21^{*}$ & 79 \\
\hline MBFG V & $18^{*}$ & 2 & - & $14 *$ & $10 *$ & $10 *$ & - & $31 *$ & 69 \\
\hline MBFG VI & $29 *$ & $13^{*}$ & $12 *$ & $5^{*}$ & $6^{*}$ & 0 & $6^{*}$ & $47 *$ & 53 \\
\hline MBFG VII & $8^{*}$ & - & 2 & $6^{*}$ & $13^{*}$ & $4^{*}$ & $8^{*}$ & $28 *$ & 72 \\
\hline All MBFGs & - & - & - & - & - & - & - & - & 100 \\
\hline
\end{tabular}

In addition, the pure contribution of the environmental (physical, chemical, and biotic) and spatial fractions (fine and broad). Values highlighted in bold and with an asterisk indicate significant fractions. Zero values indicate an explanation lower than $0.05 \%$. - represent cases in which no factors were selected

“_” indicates cases in which no factors were selected

Env environmental

period, and Mourão with $9.50 \mathrm{~mm}^{3} \mathrm{~L}^{-1}$ in the rainy period), some of them in cascade (Foz de Areia, $6.97 \mathrm{~mm}^{3} \mathrm{~L}^{-1}$ in rainy). The inocula exported from reservoirs may modify the composition and abundance of communities located in the surroundings (Chrisostomou et al. 2009) and in downstream areas (Bovo-Scomparin et al. 2013; Bortolini et al. 2017).

The effect of high dispersal was related to small flagellates with a siliceous exoskeletal structure (MBFG II), phytoplankters with medium body size without special features (MBFG IV), large flagellates (MBFG V), and colonies (MBFG VII, the only group with high dispersal in both periods). We draw attention to the effect on MBFG VII since it includes toxigenic cyanobacteria, such as Microcystis aeruginosa, which showed the highest biomass in this group (Online resource 1). This alga has a mucilaginous matrix that protects the cells when they are transported by animals. This means that an aquatic system without conditions favoring the development of $M$. aeruginosa can still contain individuals of this species, due to incoming inocula from sites with larger populations. Management measures to control populations of toxigenic algae in reservoirs should consider the relationship with surrounding habitats with high populations, and then decrease the quantity of incoming alga biomass by controlling the local populations at the source sites.

Although we did not test the pairwise relationships to determine the direction of the high export of biomass, we believe that high dispersal is more likely to occur in reservoirs located in a cascade, since high connectivity and water flow can favor dispersal of phytoplankton (Zorzal-Almeida et al. 2017; Marquardt et al. 2018; Galizia Tundisi 2018). Our biomass plot showed how in both periods, for instance, the biomass of MBFG VII decreased directionally from P5 to P6 reservoirs - the former acting as a possible source of inoculum. Future studies will be necessary to determine if such directional decrease is related to a dilutive effect due to dispersal from a highly populated source. Moreover, further research is necessary to analyze the effect of high dispersal on the homogenization of communities at taxonomic and genetic levels, and to determine, for instance, if populations of cyanobacteria of cascade reservoirs belong to the same clone.

In some cases, we observed that both limitation and highdispersal processes acted simultaneously, as in the case of large mucilaginous colonies (MBFG VII) in the rainy period. Both the distance and the connectivity among communities 
Table 5 ProTest analyses of responses of different MBFGs (or the same between periods) to environmental conditions (based on RDA)

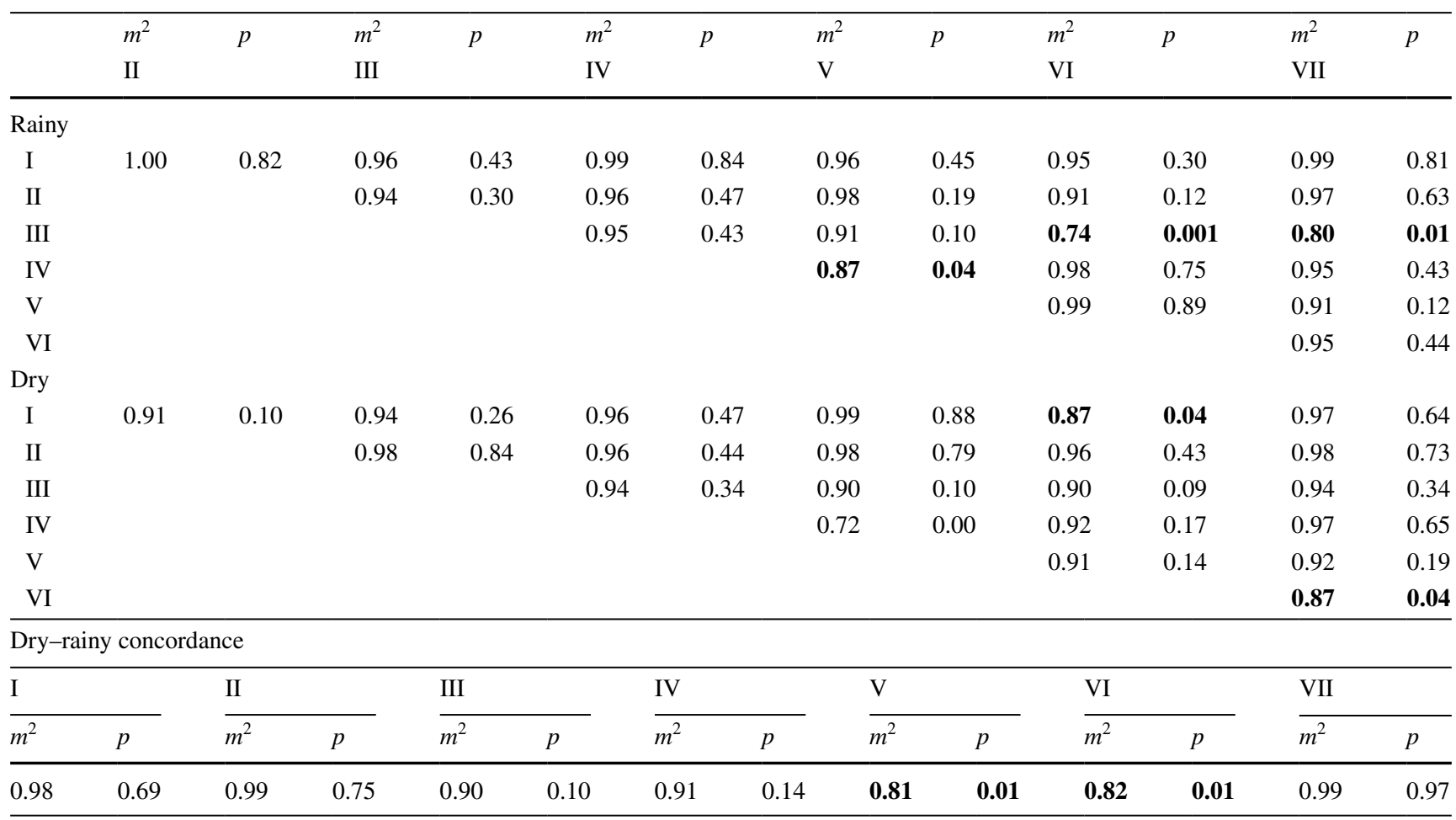

The sum of the squared residuals $\left(\mathrm{m}^{2}\right)$ is a measure of the concordance between two ordinations (comparison between functional groups). High values of $\mathrm{m}^{2}$ indicate weak concordance. Significant concordances highlighted in bold

can determine the effects of limited and high dispersal on community structure, since immigration and successful colonization depend on their dispersal efficiency over the surrounding dry land (Naselli-Flores and Padisák 2016). For our study zone, for instance, while some reservoirs were located along the same river, improving connectivity and dispersal, others belong to different basins without direct or indirect connectivity and dispersal could be more difficult.

Finally, we do not discard the possibility that the effect of both broad- and fine-scale spatial factors included in the pRDA could indicate the effect of environmental variables, important for phytoplankton, that we did not measure and that show spatial structuring (Borcard and Legendre 1994; Borcard et al. 2004, 2011).

\section{Conclusion}

Together, our results showed that the influence of the processes underlying a metacommunity (communities related by the exchanges of organisms) assemblage, such as species sorting (environmental influence), mass effect (high dispersal), and neutral dynamic (dispersal limitation), depends on the functional characteristics of the species and can still vary for species within the same trophic level.
By clarifying the kind of factors with important effects at both the taxonomic and functional levels, as well as for each kind of algae, our study may contribute to the development of management measures for organisms of publichealth interest, such as toxigenic cyanobacteria.

Supplementary Information The online version contains supplementary material available at https://doi.org/10.1007/s00027-021-00837-0.

Acknowledgements We thank the CNPq for supporting this research through Project PRONEX, and the CAPES for the doctoral study grant awarded to A Pineda. We thank Dr. Juliana Déo Dias and Dr. Luiz Felipe Machado Velho for valuable comments on the first version of this manuscript. We also acknowledge the Programa de Pós-graduação em Ecologia de Ambientes Aquáticos Continentais (PEA), the Núcleo de Pesquisas em Limnologia, Ictiologia e Aquicultura (Nupélia) from the Universidade Estadual de Maringá (UEM) for supplying infrastructure. We are grateful for the help of three anonymous reviewers and Dr. Sonja Jähnig, associate editor, who, despite the difficult situation associated with the COVID-19 pandemic, offered their time and knowledge to improve this article.

Funding Funding was provided by Conselho Nacional de Desenvolvimento Científico e Tecnológico. Open Access funding enabled and organized by Projekt DEAL.

\section{Declarations}

Conflict of interest There is no conflict of interest. 


\section{References}

Anderson MJ, Cribble NA (1998) Partitioning the variation among spatial, temporal and environmental components in a multivariate data set. Aust J Ecol 23:158-167. https://doi.org/10.1111/j. 1442-9993.1998.tb00713.x

Astorga A, Oksanen J, Luoto M et al (2012) Distance decay of similarity in freshwater communities: do macro- and microorganisms follow the same rules? Glob Ecol Biogeogr 21:365-375. https:// doi.org/10.1111/j.1466-8238.2011.00681.x

Beisner BE, Peres-Neto PR, Lindström ES et al (2006) The role of environmental and spatial processes in structuring lake communities from bacteria to fish. Ecology 87:2985-2991. https://doi.org/ 10.1890/0012-9658(2006)87[2985:TROEAS]2.0.CO;2

Borcard D, Legendre P (1994) Environmental control and spatial structure in ecological communities: an example using oribatid mites (Acari, Oribatei). Environ Ecol Stat 1:37-61. https://doi.org/10. 1007/BF00714196

Borcard D, Legendre P (2002) All-scale spatial analysis of ecological data by means of principal coordinates of neighbour matrices. Ecol Model 153:51-68. https://doi.org/10.1016/S0304-3800(01) 00501-4

Borcard D, Legendre P, Drapeau P (1992) Partialling out the spatial component of ecological variation. Ecology 73:1045-1055. https://doi.org/10.2307/1940179

Borcard D, Legendre P, Avois-Jacquet C, Tuomisto H (2004) Dissecting the spatial structure of ecological data at multiple scales. Ecology 85:1826-1832. https://doi.org/10.1890/03-3111

Borcard D, Gillet F, Legendre P (2011) Numerical ecology with R. Springer, New York

Borges PAF, Train S, Rodrigues LC (2008) Spatial and temporal variation of phytoplankton in two subtropical Brazilian reservoirs. Hydrobiologia 607:63-74. https://doi.org/10.1007/s10750-008-9367-3

Bortolini JC, Pineda A, Rodrigues LC et al (2017) Environmental and spatial processes influencing phytoplankton biomass along a reservoirs-river-floodplain lakes gradient: a metacommunity approach. Freshw Biol 62:1756-1767. https://doi.org/10.1111/ fwb. 12986

Bortolini JC, da Silva PRL, Baumgartner G, Bueno NC (2019) Response to environmental, spatial, and temporal mechanisms of the phytoplankton metacommunity: comparing ecological approaches in subtropical reservoirs. Hydrobiologia 830:45-61. https://doi.org/10.1007/s10750-018-3849-8

Bortolini JC, da Silva PRL, Baumgartner G, Bueno NC (2020) Environmental filters influencing phytoplankton taxonomic structure in cascade reservoirs. Braz J Bot 43:405-412. https://doi.org/10. 1007/s40415-020-00604-9

Bovo-Scomparin VM, Train S, Rodrigues LC (2013) Influence of reservoirs on phytoplankton dispersion and functional traits: a case study in the Upper Paraná River, Brazil. Hydrobiologia 702:115127. https://doi.org/10.1007/s10750-012-1313-8

Cassemiro FAS, Padial AA (2008) Teoria Neutra da Biodiversidade e Biogeografia: Aspectos Teóricos, Impactos na Literatura e Perspectivas. Oecologia Aust 12:706-719. https://doi.org/10.4257/ oeco.2009.1304.09

Cermeño P, de Vargas C, Abrantes F, Falkowski PG (2010) Phytoplankton biogeography and community stability in the ocean. PLoS ONE 5:e10037. https://doi.org/10.1371/journal.pone.0010037

Chrisostomou A, Moustaka-Gouni M, Sgardelis S, Lanaras T (2009) Air-dispersed phytoplankton in a Mediterranean river-reservoir system (Aliakmon-Polyphytos, Greece). J Plankton Res 31:877884. https://doi.org/10.1093/plankt/fbp038

Datry T, Bonada N, Heino J (2016) Towards understanding the organisation of metacommunities in highly dynamic ecological systems. Oikos 125:149-159. https://doi.org/10.1111/oik.02922
De Bie T, De Meester L, Brendonck L et al (2012) Body size and dispersal mode as key traits determining metacommunity structure of aquatic organisms. Ecol Lett 15:740-747. https://doi.org/10. 1111/j.1461-0248.2012.01794.x

Declerck SAJ, Winter C, Shurin JB et al (2013) Effects of patch connectivity and heterogeneity on metacommunity structure of planktonic bacteria and viruses. Int Soc Microb Ecol J 7:533-542. https://doi.org/10.1038/ismej.2012.138

Diniz-Filho JAF, Bini LM (2005) Modelling geographical patterns in species richness using eigenvector-based spatial filters. Glob Ecol Biogeogr 14:177-185. https://doi.org/10.1111/j.1466-822X.2005. 00147.x

Dray S, Bauman D, Blanchet G et al (2018) Adespatial: multivariate multiscale spatial analysis. R package version $0.3-2$. https://cran.rproject.org/package $=$ adespatial

Finlay BJ (2002) Global dispersal of free-living microbial eukaryote species. Science 296:1061-1063. https://doi.org/10.1126/science. 1070710

Galizia Tundisi J (2018) Reservoirs: new challenges for ecosystem studies and environmental management. Water Secur 4-5:1-7. https://doi.org/10.1016/j.wasec.2018.09.001

Griffith DA, Peres-Neto PR (2006) Spatial modeling in ecology: the flexibility of eigenfunction spatial analyses. Ecology 87:26032613. https://doi.org/10.1890/0012-9658(2006)87[2603:SMIETF] 2.0.CO;2

Hamar J (1977) Data of knowledge of the blue-green alga Anabaenopsis raciborskii Wolosz. Tiscia 12:17-20

Heino J, Bini LM, Karjalainen SM et al (2010) Geographical patterns of micro-organismal community structure: are diatoms ubiquitously distributed across boreal streams? Oikos 119:129-137. https://doi.org/10.1111/j.1600-0706.2009.17778.x

Heino J, Melo AS, Siqueira T et al (2015) Metacommunity organisation, spatial extent and dispersal in aquatic systems: patterns, processes and prospects. Freshw Biol 60:845-869. https://doi.org/ $10.1111 /$ fwb. 12533

Hubbell SP (2001) The unified neutral theory of biodiversity and biogeography. Princeton University Press, Princeton

Hubbell SP (2006) Neutral theory and the evolution of ecological equivalence. Ecology 87:1387-1398. https://doi.org/10.1890/ 0012-9658(2006)87[1387:ntateo]2.0.co;2

Huszar VLM, Nabout JCJC, Appel MO et al (2015) Environmental and not spatial processes (directional and non-directional) shape the phytoplankton composition and functional groups in a large subtropical river basin. J Plankton Res 13:1190-1200. https://doi. org/10.1093/plankt/fbv084

Jackson DA (1995) PROTEST: a PROcrustean Randomization TEST of community environment concordance. Écoscience 2:297-303. https://doi.org/10.1080/11956860.1995.11682297

Jensen JP, Jeppesen E, Olrik K, Kristensen P (1994) Impact of nutrients and physical factors on the shift from cyanobacterial to chlorophyte dominance in shallow Danish lakes. Can J Fish Aquat Sci 51:1692-1699

Kruk C, Segura AM (2012) The habitat template of phytoplankton morphology-based functional groups. Hydrobiologia 698:191202. https://doi.org/10.1007/s10750-012-1072-6

Kruk C, Huszar VLM, Peeters ETHM et al (2010) A morphological classification capturing functional variation in phytoplankton. Freshw Biol 55:614-627. https://doi.org/10.1111/j.1365-2427. 2009.02298.x

Kruk C, Peeters ETHM, Van Nes EH et al (2011) Phytoplankton community composition can be predicted best in terms of morphological groups. Limnol Oceanogr 56:110-118. https://doi.org/10. 4319/lo.2011.56.1.0110

Legendre P, Gallagher ED (2001) Ecologically meaningful transformations for ordination of species data. Oecologia 129:271-280. https://doi.org/10.1007/s004420100716 
Legendre P, Legendre L (1998) Numerical ecology. Elsevier, Amsterdam

Lehman JT (1991) Selective herbivory and it's role in the evolution of phytoplankton growth strategies. In: Sandgren CD (ed) Growth and reproductive strategies of freshwater phytoplankton. Cambridge University Press, Cambridge, pp 369-387

Lund J, Kipling C, Le Cren E (1958) The inverted microscope method of estimating algal numbers and the statistical basis of estimations by counting. Hydrobiologia 11:143-170

Machado KB, Teresa FB, Vieira LCG et al (2016) Comparing the effects of landscape and local environmental variables on taxonomic and functional composition of phytoplankton communities. J Plankton Res 38:1334-1346. https://doi.org/10.1093/plankt/ fbw062

Marquardt GC, Padial AA, Bicudo CEM (2018) Variance partitioning of deconstructed tropical diatom communities in reservoirs cascade. Aquat Sci 80:17. https://doi.org/10.1007/s00027-018-0571-6

Mutshinda CM, Finkel ZV, Widdicombe CE et al (2016) Ecological equivalence of species within phytoplankton functional groups. Funct Ecol 30:1714-1722. https://doi.org/10.1111/1365-2435. 12641

Naselli-Flores L, Padisák J (2016) Blowing in the wind: how many roads can a phytoplanktont walk down? A synthesis on phytoplankton biogeography and spatial processes. Hydrobiologia 764:303-313. https://doi.org/10.1007/s10750-015-2519-3

Noble IR, Slatyer RO (1980) The use of vital attributes to predict successional changes in plant communities subject to recurrent disturbances. Vegetatio 43:5-21. https://doi.org/10.1007/BF00121013

Oksanen J, Kindt R, Legendre P et al (2007) vegan: community ecology package. R package version 2.5-7. https://cran.r-project.org/ package $=$ vegan

Padial AA, Ceschin F, Declerck SAJ et al (2014) Dispersal ability determines the role of environmental, spatial and temporal drivers of metacommunity structure. PLoS ONE 9(10):e111227. https:// doi.org/10.1371/journal.pone.0111227

Padisák J (1997) Cylindrospermopsis raciborskii (Woloszynska) Seenayya et Subba Raju, an expanding, highly adaptive cyanobacterium: worldwide distribution and review of its ecology. Arch Für Hydrobiol 4:563-593

Padisák J, Soróczki-Pintér É, Rezner Z (2003) Sinking properties of some phytoplankton shapes and the relation of form resistance to morphological diversity of plankton - an experimental study. Hydrobiologia 500:243-257. https://doi.org/10.1023/A:10246 13001147

Peres-Neto PR, Legendre P, Dray S, Borcard D (2006) Variation partitioning of species data matrices: estimation and comparison of fractions. Ecology 87:2614-2625. https://doi.org/10.1890/00129658(2006)87[2614:VPOSDM]2.0.CO;2

Pineda A, Iatskiu P, Jati S et al (2020) Damming reduced the functional richness and caused the shift to a new functional state of the phytoplankton in a subtropical region. Hydrobiologia 847:3857-3875. https://doi.org/10.1007/s10750-020-04311-0

R Development Core Team (2021) R: a language and environment for statistical computing. R Foundation for Statistical Computing, Vienna

Reynolds CS (1999) Phytoplankton assemblages in reservoirs. In: Tundisi JG, Straškraba M (eds) Theorical reservoir ecology and its applications. International Institute of Ecology, Brazilian Academy of Sciences and Backhuys Publishers, São Carlos, pp $439-456$
Rodrigues LC, Pivato BM, Vieira LCG et al (2018) Use of phytoplankton functional groups as a model of spatial and temporal patterns in reservoirs: a case study in a reservoir of central Brazil. Hydrobiologia 805:147-161. https://doi.org/10.1007/s10750-017-3289-x

Salmaso N, Naselli-Flores L, Padisák J (2015) Functional classifications and their application in phytoplankton ecology. Freshw Biol 60:603-619. https://doi.org/10.1111/fwb.12520

Santana LM, Nabout JC, Ferragut C (2018) Taxonomic and functional classifications of phytoplankton in tropical reservoirs with different trophic states. Rev Bras Bot 41:91-102. https://doi.org/10. 1007/s40415-017-0428-6

Santos JBO, Silva LHS, Branco CWC, Huszar VLM (2016) The roles of environmental conditions and geographical distances on the species turnover of the whole phytoplankton and zooplankton communities and their subsets in tropical reservoirs. Hydrobiologia 764:171-186. https://doi.org/10.1007/s10750-015-2296-z

Schlichting HE (1960) The role of waterfowl in the dispersal of algae. Trans Am Microsc Soc 79:160-166

Simões NR, Nunes AH, Dias JD et al (2015) Impact of reservoirs on zooplankton diversity and implications for the conservation of natural aquatic environments. Hydrobiologia 758:3-17. https:// doi.org/10.1007/s10750-015-2260-y

Souza DG, Bueno NC, Bortolini JC et al (2016) Phytoplankton functional groups in a subtropical Brazilian reservoir: responses to impoundment. Hydrobiologia 779:47-57. https://doi.org/10.1007/ s10750-016-2798-3

Sun J, Liu D (2003) Geometric models for calculating cell biovolume and surface area for phytoplankton. J Plankton Res 25:1331-1346. https://doi.org/10.1093/plankt/fbg096

Trakhtenbrot A, Nathan R, Perry G, Richardson DM (2005) The importance of long-distance dispersal in biodiversity conservation. Divers Distrib 11:173-181. https://doi.org/10.1111/j.1366-9516. 2005.00156.x

Utermöhl H (1958) Zur Vervollkommnung der quantitativen Phytoplankton-Methodik. Mitteilungen der Int Vereinigung für Theor und Angew Limnol 9:1-38

Van der Gucht K, Cottenie K, Muylaert K et al (2007) The power of species sorting: local factors drive bacterial community composition over a wide range of spatial scales. Proc Natl Acad Sci U S A 104:20404-20409. https://doi.org/10.1073/pnas.0707200104

Wickham H (2016) ggplot2: elegant graphics for data analysis. Springer, New York

Wojciechowski J, Heino J, Mauricio L et al (2017) The strength of species sorting of phytoplankton communities is temporally variable in subtropical reservoirs. Hydrobiologia 800:31-43. https://doi. org/10.1007/s10750-017-3245-9

Zorzal-Almeida S, Soininen J, Bini LM, Bicudo DC (2017) Local environment and connectivity are the main drivers of diatom species composition and trait variation in a set of tropical reservoirs. Freshw Biol. https://doi.org/10.1111/fwb.12966.10.1111/fwb. 12966

Publisher's Note Springer Nature remains neutral with regard to jurisdictional claims in published maps and institutional affiliations. 